\begin{tabular}{l|l|l|} 
CRITICAL & $\begin{array}{l}\text { Western Ghats } \\
\text { PARTNERSHIP FUND }\end{array}$ & Special Series \\
\cline { 2 - 3 } & &
\end{tabular}

\section{THREE NEW BLACK MILDEWS FROM KERALA, INDIA}

\section{V.B. Hosagoudar ${ }^{1} \&$ A. Sabeena ${ }^{2}$}

1,2 Jawaharlal Nehru Tropical Botanic Garden \& Research Institute, Palode, Thiruvananthapuram, Kerala 695562, India

${ }^{1}$ Present address: Killa, Bilagi, Bagalkot District, Karnataka 587116, India ${ }^{1}$ vbhosagoudar@rediffmail.com (corresponding author), ${ }^{2}$ asabeenarasheed@ gmail.com

During the study of foliicolous fungi of Western Ghats in Kerala State, authors could come across three black mildew fungi infected leaves of Argyreia sp., Ficus sp. and Pavetta tomentosa. Microscopic study of these fungi revealed that they are hitherto undescribed species. Hence, they are described and illustrated here in detail.

\section{Asterina mananthavadiensis sp. nov.}

(Fig. 1; MycoBank \# 805653)

Colonies mostly epiphyllous, subdense to dense up to $3 \mathrm{~mm}$ in diameter, confluent. Hyphae substraight to flexuous, branching opposite, alternate to irregular at acute to wide angles, loosely to closely reticulate, cells 17-27 × 3-5 $\mu \mathrm{m}$. Appressoria, alternate, opposite to unilateral, antrorse to subantrorse, stellately lobate 7-12 × 5-10 $\mu \mathrm{m}$. Thyriothecia scattered to grouped, orbicular, up to $130 \mu \mathrm{m}$ in diameter, stellately dehisced at the centre, margin fimbriate; asci globose to ovate, octosporous, $20 \mu \mathrm{m}$ in diameter; ascospores conglobate, uniseptate, constricted at the septum, 12-17 $\times 7 \mu \mathrm{m}$, wall smooth. Pycnothyria orbicular, similar to thyriothecia; pycnothyriospores unicellular, pyriform, ovate, oblong 12-17 $\times$ 7-10 $\mu \mathrm{m}$.

Material examined: TBGT

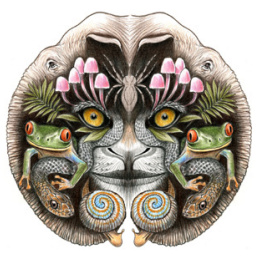

ISSN

Online 0974-7907 Print 0974-7893

\section{OPEN ACCESS} 6691 (holotype), 27.ii.2013, on leaves of Argyreia sp. (Convolvulaceae), Vellamunda, Mananthavady, Wayanad, A. Sabeena et al.

Asterina argyreiae is known on Argyreia capitata from Java (Hansford 1954). Because of its peculiarity of the appressoria it has been placed under the genus Bheemamyces (Hosagoudar et al. 2010). As such there is no Asterina species on the host genus Argyreia. Asterina mananthavadiensis differs from other Asterina species known on the members of family Convolvulaceae in having lateral and stellately lobate appressoria.

Etymology: Named after its collection locality.

\section{Meliola ficigena sp. nov.}

(Fig. 2; MycoBank \# 805651)

Colonies epiphyllous, thin to subdense, up to $2 \mathrm{~mm}$ in diameter, confluent. Hyphae substraight to undulating, branching opposite to unilateral at acute to wide angles, loosely to closely reticulate, cells 15$25 \times 5-7 \mu \mathrm{m}$. Appressoria alternate, antrorse, closely antrorse, sub antrorse to retrorse, 12-17 $\mu \mathrm{m}$ long; stalk cells cylindrical to cuneate, 2-5 $\mathrm{m}$ long; head cells ovate, globose, entire, $10-12 \times 7-10 \mu \mathrm{m}$. Phialides

DOI: http://dx.doi.org/10.11609/JoTT.03650.4898-900

Editor: R.K. Verma, Tropical Forest Research Institute, Jabalpur, India.

Date of publication: 26 October 2013 (online \& print)

Manuscript details: Ms \# 03650 | Received 06 June 2013 | Final received 30 September 2013 | Finally accepted 04 October 2013

Citation: Hosagoudar, V.B. \& A. Sabeena (2013). Three new black mildews from Kerala, India. Journal of Threatened Taxa 5(14): 4898-4900; http://dx.doi.org/10.11609/ JoTT.03650.4898-900

Copyright: (c) Hosagoudar \& Sabeena 2013. Creative Commons Attribution 3.0 Unported License. JoTT allows unrestricted use of this article in any medium, reproduction and distribution by providing adequate credit to the authors and the source of publication.

Funding: Jawaharlal Nehru Tropical Botanic Garden \& Research Institute, Palode, Thiruvananthapuram, Kerala 695562, India

Competing Interest: Authors declare no competing interests.

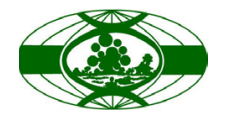

Acknowledgements: We express our gratitude to Dr. P.G. Latha, Director, JNTBGRI, Palode for the facilities.

The publication of this article is supported by the Critical Ecosystem Partnership Fund (CEPF), a joint initiative of I'Agence Française de Développement, Conservation International, the European Commission, the Global Environment Facility, the Government of Japan, the MacArthur Foundation and the World Bank. 


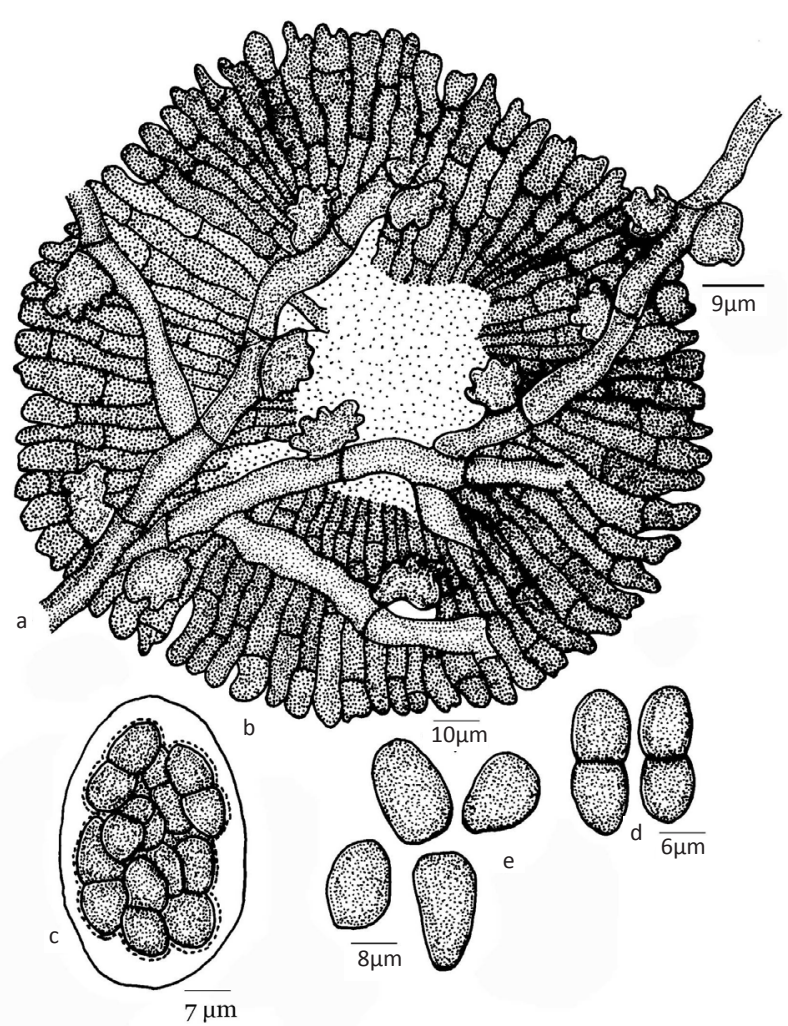

Figure 1. Asterina mananthavadiensis sp. nov.

a - Appressoriate mycelium; b - Thyriothecium; c - Ascus;

d - Ascospores; e - Pycnothyriospores

mixed with appressoria, opposite, ampulliform, 15-30 x 5-10 $\mu \mathrm{m}$. Mycelial setae scattered, simple, straight, acute to obtuse at the tip, up to $800 \mu \mathrm{m}$ long. Perithecia scattered, up to $150 \mu \mathrm{m}$ in diameter; ascospores oblong to cylindrical, 4-septate, constricted at the septa, 37-42 $x$ 17-20 $\mu \mathrm{m}$.

Materials examined: TBGT 6692 (holotype), PBL 285 (isotype), 27.iii.2009, on leaves of Ficus sp. (Moraceae), Nilakal, Pathanamthitta, Gireesh Kumar.

Based on the globose head cells of the appressoria, this species can be compared with Meliola bangalorensis Hansf. \& Thirum., collected from the Western Ghats region of Karnataka (Hansford \& Thirumalachar 1948; Hansford 1961). However, Meliola ficigena differs from it in having only entire head cells in contrast to lobed ones, and further, phialides are mixed with appressoria.

Etymology: Named after its host plant

\section{Prillieuxina pavettae sp. nov.}

(Fig. 3; MycoBank \# 805652)

Colonies mostly epiphyllous thin, up to $2 \mathrm{~mm}$ in diam., confluent. Hyphae flexuous to crooked, branching

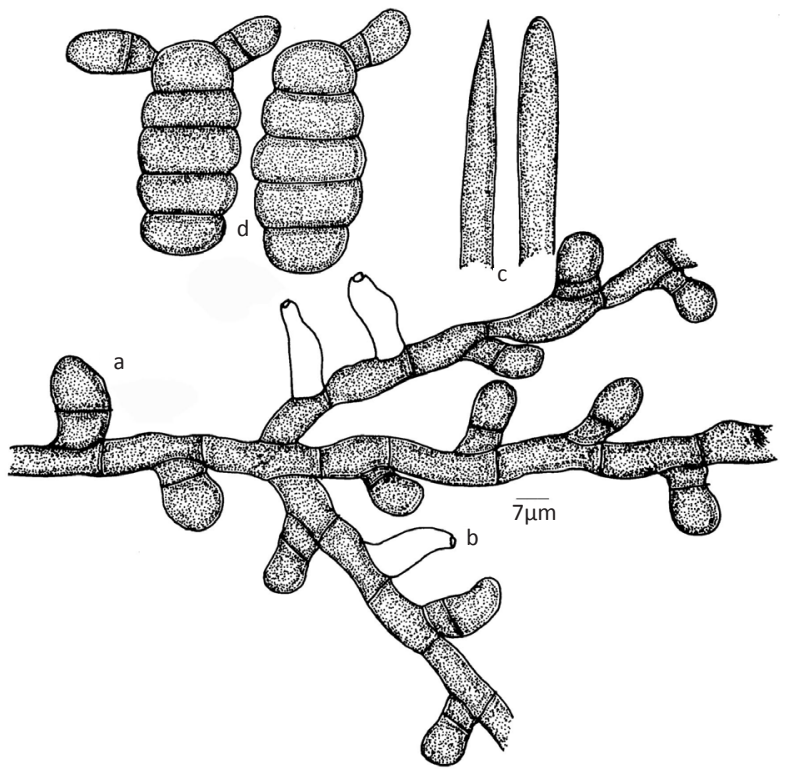

Figure 2. Meliola ficigena sp. nov.

a - Appressorium; b - Phialide; c - Apical portion of the mycelial setae; d - Ascospores

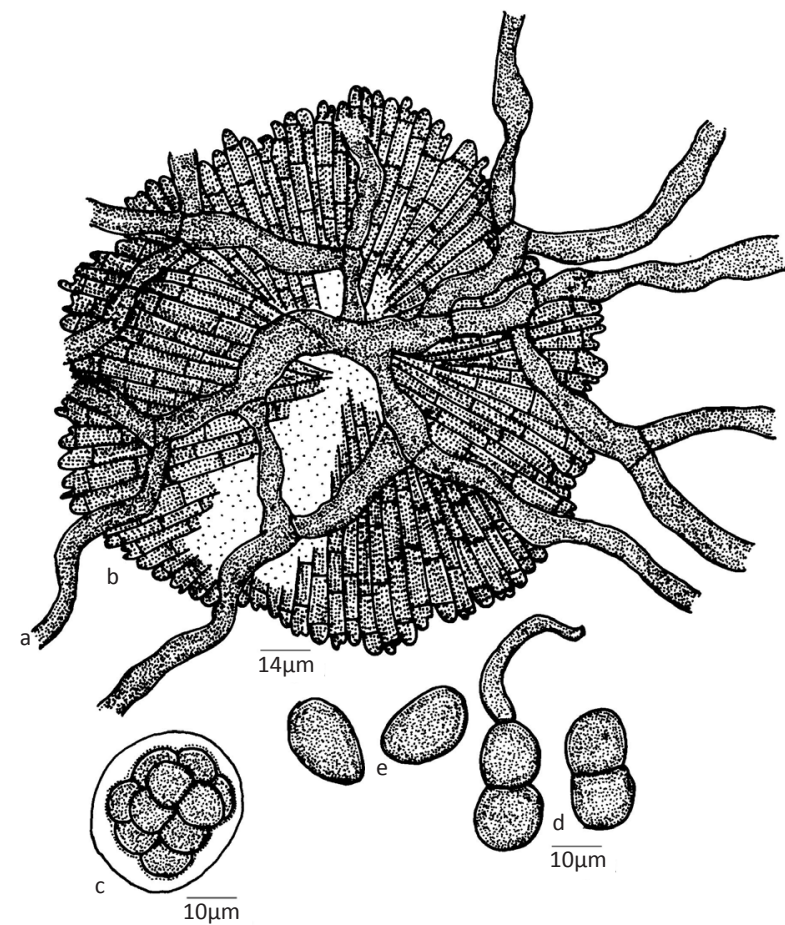

Figure 3. Prillieuxina pavettae sp. nov.

a - Mycelium; b - Thyriothecium; c - Ascus; d - Ascospores;

e - Pycnothyriospores

irregular at acute to wide angles, loosely reticulate, cells 12-25 x 5-7 $\mu \mathrm{m}$ long. Appressoria absent. Thyriothecia scattered, orbicular, up to $150 \mu \mathrm{m}$ in diam., stellately 
dehisced at the center, margin crenate; asci globose, octosporous, up to $25 \mu \mathrm{m}$ in diameter; ascospores oblong, conglobate, uniseptate, constricted at the septum, 15-25 x 7-10 $\mu \mathrm{m}$, wall smooth. Pycnothyria few, similar to thyriothecia; pycnothyriospores ovate, 20-25 x 10-15 $\mu \mathrm{m}$.

Anamorph: Asterostomula pavettae Hosag. \& A. Sabeena, Mycosphere 2(5): 837, 2012.

Material examined: TBGT 6693 (holotype), PBL 286 (isotype), 03.i.2011, on the leaves of Pavetta tomentosa Roxb. ex Smith (Rubiaceae), Chozhiyakkode, Kollam, Hosagoudar et al.

We could locate the teleomorph of this fungus and has been accommodated in a new species (Hosagoudar 2012).
Etymology: Named after its host plant.

\section{REFERENCES}

Hansford, C.G. (1954). Some Microthyriales and other fungi from Indonesia. Reinwardtia 3: 113-144.

Hansford, C.G. (1961). The Meliolaceae - A Monograph. Sydowia. Beih 2: 1-806.

Hansford, C.G. \& M.J. Tirumalachar (1948). Fungi of South India. Farlowia 3: 285-314.

Hosagoudar, V.B., A. Sabeena \& M.C. Riju (2010). Bheemamyces, a new genus of the family Asterinaceae. Journal of Threatened Taxa 2(12): 1323-1324; http://dx.doi.org/10.11609/JoTT.o2583.1323-4

Hosagoudar, V.B. (2012). Asterinales of India. Mycosphere 2(5): 617852; http://dx.doi.org/10.5943/mycosphere/3/5/9 